\title{
Toxicity and residual effects of toxic baits with spinosyns on the South American fruit fly
}

\author{
Inana Xavier Schutze ${ }^{(1)}$, Cléber Antonio Baronio(1), Morgana Mattiello Baldin ${ }^{(1)}$, \\ Alci Enimar Loek ${ }^{(2)}$ and Marcos Botton ${ }^{(1)}$
}

\begin{abstract}
(1)Embrapa Uva e Vinho, Rua Livramento, no 515, CEP 95701-008 Bento Gonçalves, RS, Brazil. E-mail: i_schutze@hotmail.com, cleber.baronio@hotmail.com, morgana.baldin13@gmail.com, marcos.botton@embrapa.br (2)Universidade Federal de Pelotas, Campus Universitário, Caixa Postal 354, CEP 96010-970 Pelotas, RS, Brazil. E-mail: alcienimar@yahoo.com.br
\end{abstract}

\begin{abstract}
The objective of this work was to assess the lethal concentration and lethal time (LC and LT) of spinosad and spinetoram, combined with different food lures, and their residual effects on South American fruit fly (Anastrepha fraterculus). The toxic baits were offered in eight concentrations $(2,6,14,35,84,204$, 495, and 1,200 $\mathrm{mg} \mathrm{L}^{-1}$ ), combined with the following food lures: 7\% sugarcane molasses, 3\% Biofruit, $1.5 \%$ CeraTrap, 1.25\% Flyral, 3\% Samaritá Bait, and 3\% Samaritá Tradicional; diluted food lures in water were used as controls. The residual effect of the formulations at $96 \mathrm{mg} \mathrm{L}^{-1}$ concentration were evaluated for 21 days and were compared with that of the commercial bait Success $0.02 \mathrm{CB}$. Both insecticides were toxic to adults of $A$. fraterculus, and mortality varied with the food lure used. The $\mathrm{LC}_{50}$ and $\mathrm{LT}_{50}$ ranged from 15.19 to $318.86 \mathrm{mg} \mathrm{L}^{-1}$ and from 11.43 to 85.93 hours, respectively. Spinosad was 2 to 36 times as toxic as spinetoram when combined with different hydrolyzed proteins. Toxic baits formulated with spinosad and spinetoram (96 mg L L $\mathrm{m}^{-1}$ caused mortality equivalent to the one by Success $0.02 \mathrm{CB}(90.2 \%)$, when assessed on the day of application. Toxic baits formulated with 3\% Biofruit + spinosad and 3\% Samaritá Bait + spinetoram are effective for managing $A$. fraterculus and provide up to seven days of residual effect in the absence of rain; however, only Success $0.02 \mathrm{CB}$ caused more than $80 \%$ mortality for up to 21 days.
\end{abstract}

Index terms: Anastrepha fraterculus, hydrolyzed protein, spinetoram, spinosad, sugarcane molasses.

\section{Toxicidade e efeitos residuais de iscas tóxicas à base de espinosinas sobre a mosca-das-frutas sul-americana}

Resumo - O objetivo deste trabalho foi determinar a concentração e o tempo letal (CL e TL) de espinosade e espinetoram, associados a diferentes atrativos alimentares, e seus efeitos residuais sobre a mosca-das-frutas sul-americana (Anastrepha fraterculus). As iscas tóxicas foram ofertadas em oito concentrações $(2,6,14$, 35, 84, 204, 495 e $1.200 \mathrm{mg} \mathrm{L}^{-1}$ ), associadas aos atrativos alimentares: 7\% de melaço de cana-de-açúcar, $3 \%$ de Biofruit, $1,5 \%$ de CeraTrap, $1,25 \%$ de Flyral, 3\% de isca Samaritá e 3\% de Samaritá Tradicional; os atrativos alimentares diluídos em água foram utilizados como testemunha. $\mathrm{O}$ efeito residual das formulações à concentração de $96 \mathrm{mg} \mathrm{L}^{-1}$ foi avaliado por 21 dias e comparado ao da isca comercial Success $0.02 \mathrm{CB}$. Ambos os inseticidas foram tóxicos aos adultos de $A$. fraterculus, e a mortalidade variou de acordo com o atrativo empregado. A $\mathrm{CL}_{50}$ e o $\mathrm{TL}_{50}$ variaram de 15,19 a $318,86 \mathrm{mg} \mathrm{L}^{-1}$ e de 11,43 a 85,93 horas, respectivamente. $\mathrm{O}$ espinosade foi de 2 a 36 vezes mais tóxico que o espinetoram quando associado às diferentes proteínas hidrolisadas. As iscas tóxicas formuladas com espinosade e espinetoram $\left(96 \mathrm{mg} \mathrm{L}^{-1}\right)$ causaram mortalidade equivalente àquela causada por Success $0.02 \mathrm{CB}(90,2 \%)$ quando avaliadas no dia da aplicação. As iscas tóxicas formuladas com Biofruit a 3\% + espinosade e isca Samaritá a 3\% + espinetoram são eficazes para o manejo de $A$. fraterculus e apresentam efeito residual de até sete dias, na ausência de chuva; porém, somente Success 0.02 CB causou mais de $80 \%$ de mortalidade por até 21 dias.

Termos para indexação: Anastrepha fraterculus, proteína hidrolisada, espinetoram, espinosade, melaço de cana-de-açúcar.

Introduction

The South American fruit fly Anastrepha fraterculus (Weidemann, 1830) (Diptera: Tephritidae) is the main fruit pest in Southern Brazil (Nava \&
Botton, 2010). Direct damage is caused by females penetrating the fruit with the ovipositor, and by the larvae developing inside the fruit (Botton et al., 2016). Indirect damage is caused by pathogens entering at the injury site, which accelerates fruit rot
Pesq. agropec. bras., Brasília, v.53, n.2, p.144-151, Feb. 2018 DOI: 10.1590/S0100-204X2018000200002 (cc) BY This is an open-access article distributed under the Creative Commons Attribution 4.0 International License 
(Machota Júnior et al., 2013). Adults and also larvae of $A$. fraterculus have been successfully controlled with organophosphate insecticides sprayed on the plants (Harter et al., 2015). However, most systemic organophosphate insecticides have been withdrawn from the market, mainly because of serious concerns about side effects on human health and the environment (Nava \& Botton, 2010; Botton et al., 2016). This scenario makes it necessary to develop new strategies for fruit fly control.

The use of toxic baits, consisting of a food lure combined with a lethal agent, is one of the main alternatives to suppress adult fruit flies as a substitute for organophosphate applications in orchards (Borges et al., 2015). The toxic bait can be formulated by the grower by mixing a food lure with a lethal agent (insecticide), or with ready-to-use formulations (as Success 0.02 CB) (Borges et al., 2015; Harter et al., 2015). However, for the toxic baits to be effective, several aspects should be taken into consideration, especially the choice of food lure as attractant (Raga et al., 2006). Sugarcane molasses is the main food lure used to formulate toxic baits in Southern Brazil (Härter et al., 2010), as sugars act as phagostimulants, increasing the amount of bait ingested (Nestel et al., 2004). Although sugarcane molasses is effective and low-cost, it is used in a high concentration (7\%), making it necessary to store large volumes in the farm; besides, as a residue of the sugarcane industry, molasses is not standardized, and it is often contaminated with substances that negatively affect the efficacy of the compound (Harter et al., 2015).

Hydrolyzed proteins are another food lure to be employed in toxic baits for fruit flies. The use of toxic baits is based on the principle that newly emerged females require a protein source to complete the development of ovaries and to begin mating (Christenson \& Foote, 1960; Bateman, 1972). Several commercial formulations of hydrolyzed proteins of both plant and animal origin are available in the market (Botton et al., 2016).

Although organophosphates are still the main insecticides employed as lethal agents in fruit fly toxic baits (Härter et al., 2010; Borges et al., 2015), spinosyns have received more attention because of their lower toxicity to humans and the environment. Spinosyns are also more selective for beneficial insects, and have shorter preharvest intervals (Galm \& Sparks, 2015).
Spinosad is the lethal agent of the commercial bait Success 0.02 CB. Spinetoram is another spinosyn derived from spinosad and consists of 3'-O-ethyl-5.6dihydro-spinosyn J (main component) and 3'-O-ethylspinosyn L (secondary component) (Galm \& Sparks, 2015). Both spinosyns have been reported as effective in controlling species of Tephritidae (Yee et al., 2007; Stark et al., 2013).

Although a commercial bait formulation with spinosad (Success $0.02 \mathrm{CB}$ ) is available, growers often prefer to mix their own toxic baits by combining different attractants with spinosyns in the farms.

The objective of this work was to assess the lethal concentration and lethal time (LC and LT) of spinosad and spinetoram, combined with different food lures, and their residual effects on South American fruit fly.

\section{Materials and Methods}

The experiments were performed in the Laboratory of Entomology of Embrapa Uva e Vinho (at $25 \pm 2^{\circ} \mathrm{C}, 75 \pm 15 \%$ relative humidity, and 12-hour photophase), in Bento Gonçalves, RS, Brazil. Adults of A. fraterculus were obtained from the fourth generation of the laboratory colony and maintained following Machota Júnior et al. (2010), using mango (Mangifera indica L. 'Tommy Atkins' as the substrate for oviposition and larval development, rather than papaya (Carica papaya L.).

Six food lures were assessed: the hydrolyzed corn protein Biofruit at 3\% (Biocontrole Método de Controle de Pragas Ltda., Indaiatuba, SP, Brazil); the enzymatic hydrolyzed animal protein CeraTrap at 1.5\% (BioIbérica S.A., Barcelona, Spain); the enzymatic hydrolyzed protein of animal origin Flyral at 1.25\% (Biolbérica S.A., Barcelona, Spain); the hydrolyzed corn protein Samaritá Bait at 3\% (Samaritá Indústria e Comércio Ltda., Artur Nogueira, SP, Brazil); the vegetable protein, with reducing sugars and preservatives Samaritá Tradicional at 3\% (Samaritá Indústria e Comércio Ltda., Artur Nogueira, SP, Brazil); and sugarcane molasses at $7 \%$. The concentrations of food lures were based on the manufacturer recommendations and on practical experience.

Toxic baits were prepared by mixing food lures with either the insecticide Tracer 480 SC (spinosad $480 \mathrm{~g} \mathrm{~L}^{-1}$ ) or Delegate $250 \mathrm{WG}$ (spinetoram $250 \mathrm{~g} \mathrm{~L}^{-1}$ ) 
(Dow AgroSciences Industrial Ltda., São Paulo, SP, Brazil). The commercial bait formulation Success 0.02 CB $\left(0.24 \mathrm{~g} \mathrm{~L}^{-1}\right)$ (Dow AgroSciences Industrial Ltda., São Paulo, SP, Brazil), diluted with water at a ratio of 1 part of the commercial product to 1.5 part of water, as recommended by the manufacturer, for a final concentration of $96 \mathrm{mg} \mathrm{L}^{-1}$ was used as a standard reference.

In order to determine the lethal concentration $\left(\mathrm{LC}_{50}\right.$ and $\left.\mathrm{LC}_{80}\right)$ of the baits, the insecticides Tracer $480 \mathrm{SC}$ (spinosad $480 \mathrm{~g} \mathrm{~L}^{-1}$ ) and Delegate $250 \mathrm{WG}$ (spinetoram $250 \mathrm{~g} \mathrm{~L}^{-1}$ ) were diluted at logarithmically sequenced concentrations $(2,6,14,35,84,204,495$, and $1,200 \mathrm{mg} \mathrm{L}^{-1}$ ) defined in previous experiments that provided mortality values from 10 to $90 \%$; in all experiments, the diluted food lures in water were used as controls. Later, 10 to 14-day-old adults of A. fraterculus from the laboratory colony were starved for 12 hours. After that time, 10 adults (five males and five females) were transferred to cages made of transparent plastic cups $(300 \mathrm{~mL})$ inverted on a paper towel (12 cm diameter). For the ventilation and gas exchange, the bottom of the cups was removed and covered with voile. The toxic baits were then offered for four hours on plastic plates $(20 \times 20 \mathrm{~mm})$ containing a drop of $40 \mu \mathrm{L}$ per cage. After that, the toxic baits were removed, and the flies fed a $10 \%$ honey solution offered via capillarity on moistened cotton wools. The mortality was assessed 96 hours after the treatment (HAT), considering as dead insects those which were unresponsive to the touch of a fine brush. The experimental design was completely randomized, with 12 replicates per treatment.

To determine the lethal time $\left(\mathrm{LT}_{50}\right.$ and $\left.\mathrm{LT}_{95}\right)$ of the bait formulations, the insecticides Tracer $480 \mathrm{SC}$ or Delegate $250 \mathrm{WG}$ were diluted at $96 \mathrm{mg} \mathrm{L}^{-1}$ of the active ingredient, using as a standard the ready-to-use bait formulation (Success $0.02 \mathrm{CB}$, at the $96 \mathrm{mg} \mathrm{L}^{-1}$ concentration), following the methodology above described. Adult mortality was assessed 2, 4, 6, 8, $10,12,14,16,18,20,22,24,36,48,60,72,84$, and 96 HAT

To evaluate the residual effect of the baits, the same LT experimental treatments were applied on leaves of citrus plants 'Valencia' grown in 5 L buckets, which contained two parts of soil and one part of vermiculite and were maintained in a greenhouse. The treatments were applied with a unicanal micropipette (Pipetman
U76928A), with one drop $(40 \mu \mathrm{L})$ of toxic bait per leaf. After $0,7,14$, and 21 days after application of the treatments, the leaves from each treatment were removed and taken to the laboratory by placing them in plastic cages $(300 \mathrm{~mL})$, using the same methodology as the experiment of lethal concentration. Insect mortality was evaluated 96 hours after the bait was provided. The experimental design was completely randomized, with 10 replicates per treatment, with five couples per replicate. Mortality was calculated with the formula by Abbott (1925).

To determine the lethal concentrations $\left(\mathrm{LC}_{50}\right.$ and $\left.\mathrm{LC}_{80}\right)$ and lethal times $\left(\mathrm{LT}_{50}\right.$ and $\left.\mathrm{LT}_{95}\right)$, and their respective confidence intervals $(95 \% \mathrm{CI})$, concentration-mortality data were subjected to Probit analysis using the program PC-Polo (Leora Software, Berkeley, CA, USA). The hypothesis that the LC and LT values were equal was evaluated with an F-test. When the hypothesis was rejected, paired comparisons were made, and significance was accepted when there was no overlap of confidence intervals (Robertson et al., 2007).

To evaluate the residual effect and the interaction among treatments (food lure, insecticide, and exposure time of adult $A$. fraterculus to toxic baits), data were subjected to two-way analysis of variance using Proc GLM in SAS 9.1, with the food lure and insecticide variables as fixed factors. The interactions between the variables were determined by least square values (PDIFF option in Proc GLM), with adjustment by the Tukey's test, at $5 \%$ probability (SAS Institute, Cary, NC, USA). Subsequently, the data for survival of adult $A$. fraterculus underwent exploratory analysis to check the normality of the residuals, and normal data were transformed by the equation [square root $(x+0.5)]$. Subsequently, the data were subjected to analysis of variance, and means were compared by the Tukey's test at $5 \%$ probability, using the SPSS program 24.0 (SPSS Inc., Chicago, IL, USA).

\section{Results and Discussion}

All toxic bait formulations were toxic to adults of A. fraterculus (Table 1). Toxic baits based on hydrolyzed proteins formulated with spinosad showed higher biological activity on adults of $A$. fraterculus, with lower $\mathrm{LC}_{50}$ and $\mathrm{LC}_{80}$ than with the spinetoram formulations (Table 1). In general, spinetoram was also 
toxic to adults of $A$. fraterculus; however, when the insecticides were combined with hydrolyzed proteins, a higher dose (2 to 36 times) was required, in order to obtain the same mortality of spinosad. This difference for mortality was not observed when the insecticides were combined with sugarcane molasses, which indicates a variation in the toxicity of compounds combined with the offered food lure. Hydrolyzed proteins resulted in lower $\mathrm{LC}_{50}$ values when combined with spinosad, while the food lure with a higher concentration of carbohydrates resulted in lower- $\mathrm{LC}_{50}$ values when combined with spinetoram, which may be related to phagostimulation caused by sugarcane molasses.

In general, food lures used for the management of fruit flies are based on a combination of hydrolyzed protein (attractant) with sugar (phagostimulant), which stimulates the insects to search for and ingest the bait (Nestel et al., 2004; Bortoli et al., 2016). Baits that contained this mixture at the same concentration resulted in a higher mortality and lower $\mathrm{LT}_{95}$ than with Success $0.02 \mathrm{CB}$ which, in addition to the lethal agent spinosad, contains a mixture of sugar, protein, ammonium acetate, and other ingredients (Yee \& Chapmamn, 2005), as well as hydrolyzed proteins of vegetable origin. Although sugarcane molasses acts as a phagostimulant due to the high concentration of sucrose (Feltrin et al., 2000; Yee \& Alston, 2016), it may not trigger the same search response.
Several studies have shown the biological activity of spinosad on A. fraterculus and suggested it as a potential replacement for malathion in toxic baits (Raga \& Sato, 2005; Harter et al., 2015). In the present study, for a mortality rate of $80 \%$, a minimum concentration of $167.41 \mathrm{mg} \mathrm{L}^{-1}$ of spinosad was required. This concentration is twice as high as the concentration found in the commercial bait Success $0.02 \mathrm{CB}$, when the insecticide was combined with the food lure Samaritá Tradicional. Raga \& Sato (2005) found 106 min of $\mathrm{LT}_{50}$ for A. fraterculus, at $80 \mathrm{mg} \mathrm{L}^{-1}$ spinosad, which is far below the more than 11 hours obtained in the present study. The difference in the LT may be related to the available volume ( $1 \mathrm{~mL}$ ) and offering period (24 hours) of the bait, which in the study by Raga \& Sato (2005) were higher than those used here $(40 \mu \mathrm{L}$ volume and 4 hours of offering period).

The lethal times (LT) of adult $A$. fraterculus exposed to toxic bait formulations containing spinosad or spinetoram, at a concentration of $96 \mathrm{mg} \mathrm{L}^{-1}$, differed significantly (Table 2). The lowest $\mathrm{LT}_{50}$ and $\mathrm{LT}_{95}$, in hours, were observed for the formulations Samaritá Tradicional + spinetoram, and Biofruit + spinosad; and the highest ones with CeraTrap + spinetoram (Table 2). These differences may be related to the speed of ingestion and subsequent assimilation of different proteins and spinosyns, which act primarily by ingestion (Vontas et al., 2011; Borges et al., 2015). Based on the overlap of confidence intervals of the $\mathrm{LT}_{95}$ values estimated for

Table 1. Lethal medium concentrations $\left(\mathrm{LC}_{50}\right.$ and $\mathrm{LC}_{80}$, in $\left.\mathrm{mg} \mathrm{L}^{-1}\right)$ of toxic-bait formulations for the control of Anastrepha fraterculus.

\begin{tabular}{|c|c|c|c|c|c|}
\hline Food lure & Insecticide & $\begin{array}{l}\text { Slope } \pm \text { standard } \\
\text { error }\end{array}$ & $\begin{array}{c}\mathrm{LC}_{50} \\
(\mathrm{CI} 95 \%)\end{array}$ & $\begin{array}{c}\mathrm{LC}_{80} \\
\text { (CI } 95 \%)\end{array}$ & $\chi^{2}$ \\
\hline \multirow{2}{*}{ Sugarcane molasses $7 \%$} & Spinosad & $0.881 \pm 0.065$ & $97.69(73.92-129.14)$ & $882.14(602.33-1418.99)$ & 5.47 \\
\hline & Spinetoram & $0.710 \pm 0.055$ & $47.10(34.40-63.71)$ & $722.66(469.18-1250.47)$ & 5.66 \\
\hline \multirow{2}{*}{ Biofruit 3\% } & Spinosad & $0.792 \pm 0.067$ & $15.19(9.34-22.73)$ & $175.64(120.56-270.74)$ & 5.49 \\
\hline & Spinetoram & $0.965 \pm 0.082$ & $84.10(59.02-115.97)$ & $626.90(434.97-981.29)$ & 5.66 \\
\hline \multirow{2}{*}{ Flyral $1.25 \%$} & Spinosad & $0.892 \pm 0.065$ & $49.69(35.08-68.80)$ & $436.50(265.10-860.30)$ & 9.09 \\
\hline & Spinetoram & $0.495 \pm 0.054$ & $318.86(193.23-606.50)$ & $15,953.00(5,644.50-76,042.00)$ & 4.86 \\
\hline \multirow{2}{*}{ CeraTrap $1.5 \%$} & Spinosad & $1.035 \pm 0.065$ & 72.11 (51.21-100.60) & $469.26(311.01-799.48)$ & 8.50 \\
\hline & Spinetoram & $0.483 \pm 0.055$ & $154.23(67.00-416.67)$ & $8,505.80(2,098.70-131,060.00)$ & 9.99 \\
\hline \multirow{2}{*}{ Samaritá Traditional 3\% } & Spinosad & $1.080 \pm 0.067$ & $27.84(18.84-39.67)$ & $167.41(112.61-275.99)$ & 9.73 \\
\hline & Spinetoram & $0.970 \pm 0.063$ & $67.73(49.51-92.21)$ & $499.56(336,38-825,57)$ & 6.49 \\
\hline \multirow{2}{*}{ Samaritá Bait 3\% } & Spinosad & $1.131 \pm 0.084$ & $50.00(37.43-64.52)$ & $277.22(213,53-374,63)$ & 4.93 \\
\hline & Spinetoram & $1.031 \pm 0.065$ & $96.19(69.24-134.32)$ & $629.70(410.48-1104.31)$ & 8.34 \\
\hline
\end{tabular}

${ }^{(1)}$ Chi-square value at $5 \%$ probability, with six degrees of freedom. 
all toxic bait formulations; only the combination of Biofruit + spinosad $\left(\mathrm{LT}_{95}=139.28\right)$ was equivalent to the ready-to-use formulation Success $0.02 \mathrm{CB}$ $\left(\mathrm{LT}_{95}=95.99\right)($ Table 2$)$. The other combinations required more time to reach $95 \%$ mortality. In general, a higher biological activity and a shorter period of time to kill the flies were obtained with the toxic baits formulated with spinosad than with spinetoram, except for the Samaritá Bait. Although both insecticides are in the same chemical group, this difference in the initial toxicity (spinosad $>$ spinetoram) was also observed for Rhagoletis pomonella (Walsh) (Yee et al., 2007). This difference may be related to different metabolic processing of spinosad and spinetoram by members of Tephritidae, since a higher biological activity was obtained with spinetoram than spinosad for insects of other families (Galm \& Sparks, 2015).

As to the residual effect at the days after the application of the treatment (DAAT), Flyral + spinetoram $96 \mathrm{mg} \mathrm{L}^{-1}$ provided the lowest mortality of adult $A$. fraterculus (61\%) at 0 DAAT, differing significantly $\left(\mathrm{F}_{20,189}=33.38 ; \mathrm{p}<0.0001\right)$ from the commercial bait formulation Success $0.02 \mathrm{CB}$ (Table 3), while the other formulations caused mortality rates from 72.6 (Flyral + spinosad $96 \mathrm{mg} \mathrm{L}^{-1}$ ) to 89.1\% (Samaritá Bait + spinosad $96 \mathrm{mg} \mathrm{L}^{-1}$ ), which is equivalent to Success $0.02 \mathrm{CB}(90.2 \%$ mortality) (Table 3). However, at 7 DAAT, only Biofruit + spinosad
$(67.9 \%)$ and Samaritá bait + spinetoram (75.5\%) performed similarly to Success $0.02 \mathrm{CB}(92.3 \%)$.

At 14 and 21 DAAT, all toxic baits formulated with food lures using spinosad or spinetoram at a concentration of $96 \mathrm{mg} \mathrm{L}^{-1}$ showed a significant decreasing mortality of adult $A$. fraterculus over time. In contrast, the commercial formulation Success 0.02 CB maintained a mortality rate above $90 \%$ until 21 DAAT (90.2\%), indicating the presence of components in the formulation that improve the stability of the active ingredient. Within this time frame, other toxic baits caused low mortality, which ranged from $17.6 \%$ (Flyral + spinosad $96 \mathrm{mg} \mathrm{L}^{-1}$ ) to $48.8 \%$ (sugarcane molasses + spinosad $96 \mathrm{mg} \mathrm{L}^{-1}$ ) (Table 3). Similar decreases in the residual activity of spinosad and spinetoram at 3 and 7 DAAT were reported for $R$. pomonella (Yee et al., 2007) and $A$. fraterculus (Borges et al., 2015; Harter et al., 2015). The short spinetoram activity period can be related to the rapid degradation of the insecticide in the presence of light (Gazit et al., 2013) or absorption by the plant, as with the spinosad, making them unavailable to the flies (Yee et al., 2007). In the case of Success 0.02 CB, the formulation contains ingredients that reduce the degradation (Flores et al., 2011), extending the period of effectiveness.

Previous studies have also shown a low residual effect of formulations of spinosad mixed with Biofruit and sugarcane molasses (Harter et al., 2015). In contrast, in the present study, Success $0.02 \mathrm{CB}$

Table 2. Lethal time in hours $\left(\mathrm{LT}_{50}\right.$ and $\left.\mathrm{LT}_{95}\right)$ of toxic bait formulations for the control of Anastrepha fraterculus.

\begin{tabular}{|c|c|c|c|c|c|}
\hline $\begin{array}{l}\text { Food } \\
\text { lure }\end{array}$ & $\begin{array}{l}\text { Insecticide } \\
\left(96 \mathrm{mg} \mathrm{L}^{-1}\right)\end{array}$ & $\begin{array}{c}\text { Slope } \pm \text { standard } \\
\text { error }\end{array}$ & $\begin{array}{c}\mathrm{LT}_{50} \\
(\mathrm{CI} 95 \%)\end{array}$ & $\begin{array}{c}\mathrm{LT}_{95} \\
\text { (CI 95\%) }\end{array}$ & $\chi^{2(1)}$ \\
\hline \multirow{2}{*}{ Sugarcane molasses $7 \%$} & Spinosad & $1.684 \pm 0.091$ & $18.79(16.48-21.29)$ & $177.99(132.91-261.00)$ & 23.58 \\
\hline & Spinetoram & $1.535 \pm 0.088$ & $16.95(14.85-19.18)$ & $199.99(146.86-300.10)$ & 21.00 \\
\hline \multirow{2}{*}{ Biofruit 3\% } & Spinosad & $1.574 \pm 0.099$ & $12.56(10.42-14.67)$ & $139.28(102.28-213.05)$ & 24.90 \\
\hline & Spinetoram & $1.355 \pm 0.085$ & $23.57(21.19-26.28)$ & $385.79(277.46-585.91)$ & 1.04 \\
\hline \multirow{2}{*}{ Flyral $1.25 \%$} & Spinosad & $1.238 \pm 0.084$ & $19.73(17.31-22.40)$ & $420.71(283.47-709.86)$ & 15.21 \\
\hline & Spinetoram & $1.170 \pm 0.087$ & $56.25(47.18-70.12)$ & $1,433.66(797.09-3,233.36)$ & 16.19 \\
\hline \multirow{2}{*}{ CeraTrap $1.5 \%$} & Spinosad & $1.234 \pm 0.085$ & $31.03(27.55-35.31)$ & $667.81(442.21-1140.93)$ & 13.37 \\
\hline & Spinetoram & $0.897 \pm 0.085$ & $85.93(67.10-120.30)$ & $5,873.6(2,460.1-2,0741.0)$ & 5.36 \\
\hline \multirow{2}{*}{ Samaritá Traditional 3\% } & Spinosad & $1.565 \pm 0.090$ & $32.21(28.40-36.98)$ & $362.30(251.43-588.35)$ & 21.72 \\
\hline & Spinetoram & $1.345 \pm 0.088$ & $11.43(9.95-12.90)$ & $190.94(144.46-272.32)$ & 7.60 \\
\hline \multirow{2}{*}{ Samaritá Bait 3\% } & Spinosad & $1.799 \pm 0.093$ & $17.52(16.06-19.05)$ & $143.76(118.11-182.23)$ & 7.20 \\
\hline & Spinetoram & $1.536 \pm 0.088$ & $18.15(15.78-20.72)$ & $213.81(153.23-334.11)$ & 23.86 \\
\hline Success $0.02 \mathrm{CB}$ & Spinosad & $2.329 \pm 0.105$ & $18.88(17.51-20.33)$ & $95.99(82.38-115.12)$ & 15.04 \\
\hline
\end{tabular}

${ }^{(1)}$ Chi-square value at $5 \%$ probability, with 15 degrees of freedom. 
(spinosad), used as a reference for mortality effects on $A$. fraterculus, showed high biological activity on the insects until 21 DAAT. Harter et al. (2015) also recorded a satisfactory mortality $(>80 \%)$ in adults of $A$. fraterculus until 7 DAAT. These results show that other factors may be affecting the residual effect of the formulations, especially the type of food lure used in the mixture with the insecticide, which may cause variation in the phagostimulation power (Nunes et al., 2013), drop size, and viscosity of the formulation (Mangan et al., 2006; Gazit et al., 2013).

The known toxicity of spinosad to A. fraterculus makes this insecticide a viable alternative for the management of pests with toxic baits (Mangan et al., 2006; Nava \& Botton, 2010; Borges et al., 2015; Galm \& Sparks, 2015; Harter et al., 2015). The present study showed that spinetoram can also be employed, as it caused more than $80 \%$ mortality. A. fraterculus proved to be less susceptible to spinetoram when combined with an attractant containing protein ingredients, but had the same residual effect as spinosad at the same concentration. This was found for the formulation with Samarita Bait that remained effective for 7 days, which is equivalent to the residual effect observed for spinosad combined with Biofruit.

The toxic baits made with spinosyns caused a high mortality in adults of $A$. fraterculus, although the effective concentration of the lethal agent varied depending on the food lure (Tables 1, 2 and 3). Considering as acceptable an $80 \%$ mortality rate of adults of $A$. fraterculus, and comparing the

Table 3. Mean number of Anastrepha fraterculus alive $(\mathrm{N} \pm \mathrm{SE})$ and percentage of mortality (M\%) 96 hours after exposure to residues of toxic baits made with spinosad and spinetoram, on citrus leaves at $0,7,14$, and 21 days after application of the treatments $(\mathrm{DAAT})^{(1)}$.

\begin{tabular}{|c|c|c|c|c|c|c|c|c|}
\hline \multirow{2}{*}{$\begin{array}{l}\text { Active ingredient } \\
\left(96 \mathrm{mg}^{-1} \mathrm{~L}^{-1}\right)\end{array}$} & \multicolumn{2}{|l|}{0} & \multicolumn{2}{|l|}{7} & \multicolumn{2}{|l|}{14} & \multicolumn{2}{|l|}{21} \\
\hline & $\mathrm{N} \pm \mathrm{SE}$ & $\mathrm{M} \%{ }^{(2)}$ & $\mathrm{N} \pm \mathrm{SE}$ & $\mathrm{M} \%$ & $\mathrm{~N} \pm \mathrm{SE}$ & M\% & $\mathrm{N} \pm \mathrm{SE}$ & $\mathrm{M} \%$ \\
\hline & \multicolumn{8}{|c|}{ Sugarcane molasses 7\% } \\
\hline Spinosad & $1.7 \pm 0,47 \mathrm{~Eb}$ & 82.2 & $4.5 \pm 0.49 \mathrm{DEFGab}$ & 70.0 & $2.6 \pm 0.40 \mathrm{CDa}$ & 49.4 & $4.9 \pm 0.57 \mathrm{EFa}$ & 48.8 \\
\hline \multirow[t]{3}{*}{ Spinetoram } & $1.8 \pm 0,54 \mathrm{Ec}$ & 81.3 & $3.0 \pm 0.50 \mathrm{EFGbc}$ & 61.8 & $4.0 \pm 0.42 \mathrm{Db}$ & 53.8 & $6.0 \pm 0.37 \mathrm{BCDEFa}$ & 37.3 \\
\hline & $9.6 \pm 0,28 \mathrm{Aa}$ & - & $8.9 \pm 0.30 \mathrm{Aab}$ & - & $8.7 \pm 0.31 \mathrm{Aab}$ & - & $9.6 \pm 0.19 \mathrm{Aa}$ & - \\
\hline & \multicolumn{8}{|c|}{ Biofruit 3\% } \\
\hline Spinosad & $1.3 \pm 0,35 \mathrm{~Eb}$ & 85.2 & $1.5 \pm 0.53 \mathrm{FGHa}$ & 67.9 & $4.3 \pm 0.49 \mathrm{BCDa}$ & 40.8 & $5.9 \pm 0.63 \mathrm{DEFa}$ & 34.8 \\
\hline \multirow[t]{3}{*}{ Spinetoram } & $1.9 \pm 0.48 \mathrm{~Eb}$ & 78.4 & $4.6 \pm 0.43 \mathrm{BCDEFa}$ & 47.6 & $4.7 \pm 0.49 \mathrm{BCDa}$ & 47.2 & $4.6 \pm 0.56 \mathrm{EFa}$ & 35.9 \\
\hline & $8.8 \pm 0.38 \mathrm{Aa}$ & - & $8.1 \pm 0.25 \mathrm{ABCDa}$ & - & $8.6 \pm 0.35 \mathrm{Tab}$ & - & $8.8 \pm 0.34 \mathrm{ABCDa}$ & - \\
\hline & \multicolumn{8}{|c|}{ CeraTrap $1.5 \%$} \\
\hline Spinosad & $2.0 \pm 0.77 \mathrm{~Eb}$ & 78.1 & $3.8 \pm 0.59 \mathrm{BCDE} \mathrm{ab}$ & 54.6 & $5.9 \pm 0.66 \mathrm{BCDa}$ & 33.5 & $5.8 \pm 0.47 \mathrm{ABCDEFa}$ & 34.0 \\
\hline \multirow[t]{3}{*}{ Spinetoram } & $2.1 \pm 0.35 \mathrm{DEb}$ & 76.3 & $4.6 \pm 0.33 \mathrm{CDEFa}$ & 46.3 & $4.3 \pm 0.42 \mathrm{ABCDa}$ & 46.2 & $5.3 \pm 0.64 \mathrm{Fa}$ & 34.5 \\
\hline & $9.1 \pm 0.33 \mathrm{Aa}$ & - & $8.7 \pm 0.26 \mathrm{Aab}$ & - & $8.6 \pm 0.34 \mathrm{ABCa}$ & - & $9.4 \pm 0.21 \mathrm{Aab}$ & - \\
\hline & \multicolumn{8}{|c|}{ Flyral $1.25 \%$} \\
\hline Spinosad & $1.9 \pm 0.58 \mathrm{DEb}$ & 72.7 & $3.6 \pm 0.55 \mathrm{EFGab}$ & 52.2 & $4.4 \pm 0.63 \mathrm{ABCDa}$ & 32.2 & $6.6 \pm 0.70 \mathrm{ABCDEa}$ & 17.6 \\
\hline \multirow{3}{*}{ Spinetoram } & $3.6 \pm 0.38 \mathrm{CDab}$ & 61.0 & $4.4 \pm 0.44 \mathrm{DEFa}$ & 50.0 & $4.4 \pm 0.62 \mathrm{Of}$ & 49.2 & $4.8 \pm 0.72 \mathrm{EFa}$ & 47.3 \\
\hline & $8.8 \pm 0.37 \mathrm{Aa}$ & - & $9.3 \pm 0.34 \mathrm{Aab}$ & - & $8.7 \pm 0.35 \mathrm{Aab}$ & - & $9.1 \pm 0.37 \mathrm{ABCa}$ & - \\
\hline & \multicolumn{8}{|c|}{ Samaritá Bait 3\% } \\
\hline Spinosad & $1.0 \pm 0.32 \mathrm{~Eb}$ & 89.1 & $3.8 \pm 0.86 \mathrm{BCDEFa}$ & 57.8 & $5.5 \pm 0.78 \mathrm{BCDa}$ & 41.3 & $5.9 \pm 0.65 \mathrm{CDEFa}$ & 36.2 \\
\hline \multirow[t]{3}{*}{ Spinetoram } & $1.7 \pm 0.40 \mathrm{Ec}$ & 81.5 & $2.3 \pm 0.57 \mathrm{FGHbc}$ & 75.5 & $4.3 \pm 0.74 \mathrm{Dab}$ & 52.2 & $6.1 \pm 0.54 \mathrm{ABCDEFa}$ & 25.0 \\
\hline & $9.2 \pm 0.24 \mathrm{Aa}$ & - & $9.4 \pm 0.39 \mathrm{Aa}$ & - & $9.0 \pm 0.29 \mathrm{Aab}$ & - & $9.3 \pm 0.23 \mathrm{Aa}$ & - \\
\hline & \multicolumn{8}{|c|}{ Samaritá Traditional3\% } \\
\hline Spinosad & $2.2 \pm 0.42 \mathrm{DEb}$ & 75.9 & $3.9 \pm 0.61 \mathrm{BCDEFa}$ & 57.1 & $5.2 \pm 0.40 \mathrm{BCDa}$ & 42.9 & $5.2 \pm 0.44 \mathrm{EFb}$ & 36.1 \\
\hline \multirow[t]{3}{*}{ Spinetoram } & $1.2 \pm 0.37 \mathrm{Ec}$ & 86.8 & $3.0 \pm 0.47 \mathrm{DEFGb}$ & 67.2 & $4.3 \pm 0.62 \mathrm{CDb}$ & 47.2 & $6.2 \pm 0.51 \mathrm{ABCDEFa}$ & 32.0 \\
\hline & $9.0 \pm 0.35 \mathrm{Aa}$ & - & $8.1 \pm 0.37 \mathrm{ABCa}$ & - & $9.1 \pm 0.37 \mathrm{Aa}$ & - & $9.1 \pm 0.33 \mathrm{ABCa}$ & - \\
\hline & \multicolumn{8}{|c|}{ Success $0.02 \mathrm{CB}$} \\
\hline Spinosad & $0.5 \pm 0.16 \mathrm{Ea}$ & 90.2 & $0.8 \pm 0.39 \mathrm{Ha}$ & 92.3 & $0.8 \pm 0.28 \mathrm{Ea}$ & 94.2 & $0.9 \pm 0.39 \mathrm{Ga}$ & 90.2 \\
\hline Water & $8.1 \pm 0.28 \mathrm{ABb}$ & - & $9.1 \pm 0.24 \mathrm{Aab}$ & - & $8.6 \pm 0.21 \mathrm{ABab}$ & - & $9.2 \pm 0.24 \mathrm{Aab}$ & - \\
\hline
\end{tabular}


two spinosyns at the same concentrations in the toxic bait Success $0.02 \mathrm{CB}$, only the commercial formulation provided a satisfactory control until 21 DAAT. The remaining toxic bait formulations were equivalent to commercial formulation only on the day of application, highlighting the formulations Biofruit + spinosad and Samaritá Bait + espinetoram) at 7 DAAT, common period of reapplication of toxic baits in the field (Raga, 2005; Harter et al., 2015). The use of higher concentrations of spinosyns in the bait formulations could cause a mortality increase, since the assessed concentration $\left(96 \mathrm{mg} \mathrm{L}^{-1}\right)$ is less than all $\mathrm{LC}_{80}$ values obtained. Considering the best food lure combinations with the spinosyns, the minimum concentration of spinosad and spinetoram that should be employed would be $167.41 \mathrm{mg} \mathrm{L}^{-1}$ and $499.56 \mathrm{mg} \mathrm{L}^{-1}$, respectively, with the Biofruit and Samaritá Tradicional lures.

The biological activity of the products varies according to the type of food lure used. Spinosad is generally more active than spinetoram at the same concentrations using attractants based on hydrolyzed protein. The use of spinosad or spinetoram in toxic bait formulations allows growers to use these insecticides for the management of adult $A$. fraterculus close to the harvest period, with lower risks of leaving toxic residues on the fruit. Besides its greater biological activity than spinetoram, spinosad is accepted for use on organic crops abroad (OMRI, 2016). However, in Brazil, spinosad is not authorized for employment on most fruits from temperate climates (Agrofit, 2016) and, in these cases, spinetoram can be an alternative to organophosphates as a lethal agent.

\section{Conclusions}

1. Spinosad and spinetoram are toxic to adults of the South American fruit fly (Anastrepha fraterculus) in bait formulations, but the biological activity of the products varies according to the type of food lure used.

2. Toxic baits formulated with Biofruit at 3\%+ spinosad and Samaritá Bait at 3\%+ spinetoram are effective for the management of $A$. fraterculus and provide up to seven days of residual effect.

\section{Acknowledgments}

To Conselho Nacional de Desenvolvimento Científico e Tecnológico (CNPq) and Fundação de
Amparo à Pesquisa do Estado do Rio Grande do Sul (Fapergs), for financial support to the project; to Coordenação de Aperfeiçoamento de Pessoal de Nível Superior (Capes), for providing a scholarship to the first author; and to Dr. Daniel Bernardi, for aid with the reviews and statistical analyses.

\section{References}

ABBOTT, W.S. A method of computing the effectiveness of an insecticide. Journal of Economic Entomology, v.18, p.265-267, 1925. DOI: $10.1093 /$ jee/18.2.265a.

AGROFIT. Sistema de Agrotóxicos Fitossanitários. Pragas. Available at: <http://agrofit.agricultura.gov.br/agrofit_cons/ principal_agrofit_cons>. Accessed on: Dec. 102016.

BATEMAN, M.A. The ecology of fruit flies. Annual Review of Entomology, v.17, p.493-518, 1972. DOI: 10.1146/annurev. en.17.010172.002425.

BORGES, R.; MACHOTA JÚNIOR, R.; BOFF, M.I.C.; BOTTON, M. Efeito de iscas tóxicas sobre Anastrepha fraterculus (Wiedemann) (Diptera: Tephritidae). BioAssay, v.10, p.1-8, 2015. DOI: 10.14295/BA.v10.134.

BORTOLI, L.C.; MACHOTA JÚNIOR, R.; GARCIA, F.R.M.; BOTTON, M. Evaluation of food lures for fruit flies (Diptera: Tephritidae) captured in a citrus orchard of the Serra Gaúcha. Florida Entomologist, v.99, p.381-384, 2016. DOI: 10.1653/024.099.0307.

BOTTON, M.; ARIOLI, C.J.; MACHOTA JÚNIOR, R.; NUNES, M.Z.; ROSA, J. M. da. Moscas-das-frutas na fruticultura de clima temperado: situação atual e perspectivas de controle através do emprego de novas formulações de iscas tóxicas e da captura massal. Agropecuária Catarinense, v.29, p.103-108, 2016.

CHRISTENSON, L.D.; FOOTE, R.H. Biology of fruit flies. Annual Review of Entomology, v.5, p.171-192, 1960. DOI: 10.1146/annurev.en.05.010160.001131.

FELTRIN, V.P.; SANT'ANNA, E.S.; PORTO, A.C.S.; TORRES, R.C.O. Produção de Lactobacillus plantarum em melaço de canade-açúcar. Brazilian Archives of Biology and Technology, v.43, 2000. DOI: 10.1590/S1516-89132000000100015.

FLORES, S.; GOMEZ, L.E.; MONTOYA, P. Residual control and lethal concentrations of GF-120 (spinosad) for Anastrepha spp. (Diptera: Tephritidae). Journal of Economic Entomology, v.104, p.1885-1891, 2011. DOI: 10.1603/EC10365.

GALM, U.; SPARKS, T.C. Natural product derived insecticides: discovery and development of spinetoram. Journal of Industrial Microbiology and Biotechnology, v.43, p.185-193, 2015. DOI: 10.1007/s10295-015-1710-x.

GAZIT, Y.; GABRIEL, S.; AKIVA, R.; TIMAR, D. Toxicity of baited spinosad formulations to Ceratitis capitata: from the laboratory to the application. Entomologia Experimentalis et Applicata, v.147, p.120-125, 2013. DOI: 10.1111/eea.12051.

HARTER, W.R.; BOTTON, M.; NAVA, D.E.; GRUTZMACHER, A.D.; GONÇALVES, R. da S.; MACHOTA JÚNIOR, R.; 
BERNARDI, D.; ZANARDI, O.Z. Toxicities and residual effects of toxic baits containing spinosad or malathion to control the adult Anastrepha fraterculus (Diptera: Tephritidae). Florida Entomologist, v.98, p.202-208, 2015. DOI: 10.1653/024.098.0135.

HÄRTER, W. da R.; GRÜTZMACHER, A.D.; NAVA, D.E.; GONÇALVES, R. da S.; BOTTON, M. Isca tóxica e disrupção sexual no controle da mosca-das-frutas sul-americana e da mariposa-oriental em pessegueiro. Pesquisa Agropecuária Brasileira, v.45, p.229-235, 2010. DOI: 10.1590/S0100204X2010000300001.

MACHOTA JÚNIOR, R.; BORTOLI, L.C.; BOTTON, M.; GRUTZMACHER, A.D. Fungi that cause rot in bunches of grape identified in adult fruit flies (Anastrepha fraterculus) (Diptera: Tephritidae). Chilean Journal of Agricultural Research, v.73, p.196-201, 2013. DOI: 10.4067/S0718-58392013000200018.

MACHOTA JÚNIOR, R.; BORTOLI, L.C.; TOLOTTI, A.; BOTTON, M. Técnica de criação de Anastrepha fraterculus (Wied., 1830) (Diptera: Tephritidae) em laboratório utilizando hospedeiro natural. Bento Gonçalves: Embrapa Uva e Vinho, 2010. 23p. (Embrapa Bento Gonçalves. Boletim de pesquisa e desenvolvimento, 15). Available at: $<$ http://www.cnpuv.embrapa. br/publica/boletim/bop015.pdf>. Accessed on: Aug. 282015.

MANGAN, R.L.; MORENO, D.S.; THOMPSON, G.D. Bait dilution, spinosad concentration, and efficacy of GF-120 based fruit fly sprays. Crop Protection, v.25, p.125-133, 2006. DOI: 10.1016/j.cropro.2005.03.012.

NAVA, D.E.; BOTTON, M. Bioecologia e controle de Anastrepha fraterculus e Ceratitis capitata em pessegueiro. 2010. Available at: <http://www.infoteca.cnptia.embrapa.br/infoteca/bitstream/ doc/889693/4/CPACTDocumento315.pdf > . Accessed on: Aug. 25 2015.

NESTEL, D.; NEMNY-LAVY, E.; ZILBERG, L.; WEISS, M.; AKIVA, R.; GAZIT, Y. The fruit fly PUB: a phagostimulation unit bioassay system to quantitatively measure ingestion of baits by individual flies. Journal of Applied Entomology, v.128, p.576-582, 2004. DOI: 10.1111/j.1439-0418.2004.00895.x.

NUNES, M.Z.; SANTOS, R.S.S.; BOFF, M.I.C.; ROSA, J.M. Avaliação de atrativos alimentares na captura de Anastrepha fraterculus (Widemann, 1830) (Diptera: Tephritidae) em pomar de macieira. Revista de la Facultad de Agronomía, v.112, p.9196, 2013.
OMRI. Organic Materials Review Institute. Products list. 2016. Available at: <http://www.omri.org/sites/default/files/opl_pdf/ CropByCategory-NOP.pdf $>$. Accessed on: Jan. 82017.

RAGA, A. Incidência, monitoramento e controle de moscas-dasfrutas na Citricultura Paulista. Laranja, v.26, p.307-322, 2005.

RAGA, A.; MACHADO, R.A.; DINARDO, W.; STRIKIS, P.C. Eficácia de atrativos alimentares na captura de moscas-das-frutas em pomar de citros. Bragantia, v.65, p.337-345, 2006. DOI: 10.1590/S0006-87052006000200016.

RAGA, A.; SATO, M.E. Effect of spinosad bait against Ceratitis capitata (Wied.) and Anastrepha fraterculus (Wied.) (Diptera: Tephritidae) in laboratory. Neotropical Entomology, v.34, p.815822, 2005. DOI: 10.1590/S1519-566X2005000500014.

ROBERTSON, J.L.; SAVIN, N.E.; RUSSELL, R.M.; PREISLER, H.K. Bioassays with arthropods. Boca Raton: CRC Press, 2007. $199 \mathrm{p}$.

STARK, J.D.; VARGAS, R.I.; SOUDER, S.L.; FOX, A.J.; SMITH, T.R.; MACKEY, B. A comparison of the bioinsecticide, spinosad, the semi-synthetic insecticide, spinetoram and synthetic insecticides as soil drenches for control of tephritid fruit flies. Biopesticides International, v.9, p.120-126, 2013.

VONTAS, J.; HERNÁNDEZ-CRESPO, P.; MARGARITOPOULOS, J.T.; ORTEGO, F.; FENG, H.-T.; MATHIOPOULOS, K.D.; HSU, J. Insecticide resistance in Tephritid flies. Pesticide Biochemistry and Physiology, v.100, p.199-205, 2011. DOI: 10.1016/j.pestbp.2011.04.004.

YEE, W.L.; ALSTON, D.G. Sucrose mixed with spinosad enhances kill and reduces oviposition of Rhagoletis indifferens (Diptera: Tephritidae) under low food availability. Journal of Entomological Science, v.51, p.101-112, 2016. DOI: 10.18474/ JES15-33.1.

YEE, W.L.; CHAPMAN, P.S. Effects of GF-120 fruit fly bait concentrations on attraction, feeding, mortality, and control of Rhagoletis indifferens (Diptera: Tephritidae). Journal of Economic Entomology, v.98, p.1654-1663, 2005. DOI: 10.1093/ jee/98.5.1654.

YEE, W.L.; JACK, O.; NASH, M.J. Mortality of Rhagoletis pomonella (Diptera: Tephritidae) exposed to field-aged spinetoram, GF-120, and azinphos-methyl in Washington state. Florida Entomologist, v.90, p.335-342, 2007. DOI: 10.1653/0015-4040(2007)90[335:MORPDT]2.0.CO;2.

$\overline{\text { Received on February 5, } 2016 \text { and accepted on June 20, } 2016}$ 